\title{
Episodic ataxia type 6
}

INSERM

\section{Source}

INSERM. (1999). Orphanet: an online rare disease and orphan drug data base. Episodic ataxia type 6. ORPHA:209967

Episodic ataxia type 6 (EA6) is an exceedingly rare form of Hereditary episodic ataxia (see this term) with varying degrees of ataxia and associated findings including slurred speech, headache, confusion and hemiplegia. 